Article

\title{
Evaluation of Different Methods for Cultivating Gluconacetobacter hansenii for Bacterial Cellulose and Montmorillonite Biocomposite Production: Wound-Dressing Applications
}

\author{
Katharine Valéria Saraiva Hodel ${ }^{1}$, Larissa Moraes dos Santos Fonseca ${ }^{1}$, \\ Isa Moreira da Silva Santos ${ }^{2} \mathbb{D}$, Jamile Costa Cerqueira ${ }^{1}$, \\ Raimundo Evangelista dos Santos-Júnior ${ }^{2}$, Silmar Baptista Nunes ${ }^{2}$, \\ Josiane Dantas Viana Barbosa ${ }^{1}$ iD and Bruna Aparecida Souza Machado ${ }^{1, *(\mathbb{C})}$ \\ 1 University Center SENAI CIMATEC, National Service of Industrial Learning, Laboratory of \\ Pharmaceutical's Formulations, Health Institute of Technologies (ITS CIMATEC), Salvador 41650-010, Brazil; \\ katharine.hodel@fbter.org.br (K.V.S.H.); larissa.fonseca@fbter.org.br (L.M.d.S.F.); \\ jamilecosta@msn.com (J.C.C.); josianedantas@fieb.org.br (J.D.V.B.) \\ 2 University Center SENAI CIMATEC, National Service of Industrial Learning, Salvador 41650-010, Brazil; \\ isamoreira@outlook.com.br (I.M.d.S.S.); rjs.evangelista@gmail.com (R.E.d.S.-J.); silmar@fieb.org.br (S.B.N.) \\ * Correspondence: brunam@fieb.org.br; Tel.: +55-(71)-3879-5624
}

Received: 1 December 2019; Accepted: 1 January 2020; Published: 26 January 2020

\begin{abstract}
Bacterial cellulose (BC) has received considerable attention due to its unique properties, including an ultrafine network structure with high purity, mechanical strength, inherent biodegradability, biocompatibility, high water-holding capacity and high crystallinity. These properties allow BC to be used in biomedical and industrial applications, such as medical product. This research investigated the production of BC by Gluconacetobacter hansenii ATCC 23769 using different carbon sources (glucose, mannitol, sucrose and xylose) at two different concentrations ( 25 and $50 \mathrm{~g} \cdot \mathrm{L}^{-1}$ ). The BC produced was used to develop a biocomposite with montmorillonite (MMT), a clay mineral that possesses interesting characteristics for enhancing BC physical-chemical properties, at 0.5, 1, 2 and $3 \%$ concentrations. The resulting biocomposites were characterized in terms of their physical and barrier properties, morphologies, water-uptake capacities, and thermal stabilities. Our results show that bacteria presented higher BC yields in media with higher glucose concentrations $\left(50 \mathrm{~g} \cdot \mathrm{L}^{-1}\right)$ after a 14-day incubation period. Additionally, the incorporation of MMT significantly improved the mechanical and thermal properties of the $\mathrm{BC}$ membranes. The degradation temperature of the composites was extended, and a decrease in the water holding capacity (WHC) and an improvement in the water release rate (WRR) were noted. Determining a cost-effective medium for the production of $\mathrm{BC}$ and the characterization of the produced composites are extremely important for the biomedical applications of BC, such as in wound dressing materials.
\end{abstract}

Keywords: bacterial cellulose; biocomposites; montmorillonite; wound dressing; ex situ production; carbon sources; Gluconacetobacter hansenii

\section{Introduction}

Bacterial cellulose $(\mathrm{BC})$ is a natural biopolymer that is achieving worldwide attention because of its simple and feasible production technology. $\mathrm{BC}$ has the same chemical formula of plant cellulose $\left(\mathrm{C}_{6} \mathrm{H}_{10} \mathrm{O}_{5}\right) \mathrm{n}$ with $\beta$-D-glucopyranose units interlinked by intermolecular hydrogen bonds [1,2] However, unlike plant cellulose, $\mathrm{BC}$ has an ultrafine network structure with high porosity and thinner 
fibrils (nanometers sized). Moreover, BC possesses distinguished features, such as high purity (free of lignin, hemicellulose, and pectin), high degree of polymerization, high crystallinity, high water content, high mechanical stability and great chemical modifying ability [3-6]. These unique characteristics make BC a promising alternative to plant-derived cellulose for several biomedical applications being widely studied, including wound dressing materials [7-9].

Development and application of natural polymer-based wound dressing has been described in various studies and patents in recent years [10-14]. Traditional dressings, such as gauze, lint, plasters, bandages (natural or synthetic) and cotton wool, have limitations in epidermal or skin damage or burns, as they fail to prevent the growth of microbial infections and provide a moist environment for healing [15]. An ideal dressing not only covers and protects the affected area but also optimizes the wound environment to facilitate healing $[9,15]$. Biomedical applications of $\mathrm{BC}$ have received considerable attention, for example, in wound dressing [16,17], scaffold implants [6] skin and bone tissue engineering [18] and delivery systems of drug [19,20].

The moisture retaining property of $\mathrm{BC}$ helps to maintain homeostasis, aid healing, reduce pain, minimize scar formation and increase the epithelialization rate; thus, $\mathrm{BC}$ represents a great alternative to traditional dressings [9,15]. Additionally, $\mathrm{BC}$ constitutes a great matrix for the synthesis of functional composites due to its huge nanoporous area and the presence of oxygen atoms rich in electrons [15,21-23]. Therefore, some researchers have investigated BC-reinforced polymer composites with different materials, including conducting materials [24], graphene oxide [20], carbon nanotubes [25], ceramics [26], and biopolymers [27], for various biotechnological applications.

In the past few years, polymer nanocomposites with numerous clays have been extensively investigated mainly due to their cost effectiveness and possible applicability in various areas, including structural, electronics, and biomedical industries [28-30]. Montmorillonite (MMT) is a surface-reactive hydroxyl-layered aluminum silicate clay mineral that forms microscopic platinum crystals [31]. MMT is one of the most widely used medicinal clays and has interesting properties for wound dressing applications, such as wound healing and antimicrobial properties, cleansing, skin protection, blood clotting and hemorrhage control in trauma patients [21,32,33]. As dressing material, MMT has been demonstrated by previous studies to be able to enhance the $\mathrm{BC}$ wound healing properties by adding to its antibacterial properties and improving its physical-mechanical and thermal properties [21,32,34,35].

Among cellulose producing bacteria, the most effective species are from the Gluconacetobacter genus (also named as Acetobacter) [36,37]. When these species are grown in a laboratory under static conditions, cellulose forms as a swollen membrane in the air-water interface, which increases in thickness if cultivation time increases [37]. There are several reports of the use of different media and carbon sources in the literature [38-41]. However, the low yield of the static production process and the high production cost of $\mathrm{BC}$ have restricted the commercial efficacy of BC. Finding an optimal culture medium and appropriate growth conditions that facilitate higher yields of cellulose would aid in the viability of this technology in an industrial situation.

Therefore, in this study, we evaluated BC membrane production by Gluconacetobacter hansenii ATCC 23769 under static conditions using different carbon sources (glucose, sucrose, maltose, and xylitol) at different concentrations. The BC produced was used to synthesize BC-MMT biocomposites with $0.5,1$, and $2 \%$ MMT to produce a biomaterial with enhanced physical-mechanical properties for biomedical field applications as a dressing material. The properties of the BC-MMT composites, including mechanical strength, thermal stability, water holding capacity (WHC), and water release rate (WRR), were investigated to determine their suitability for applications in various fields. The results demonstrated that the use of a clay mineral such as MMT improves the physical-mechanical properties of BC, making it able to be used as wound dressing. These findings elucidate BC-MMT composites as a promising alternative for various medical treatments such as wound healing and repair of damaged tissue. 


\section{Materials and Methods}

Figure 1 illustrates the complete methodology used in the production of the BC and BC-MMT biocomposites. BC was produced by inoculating G. hansenii ATCC 23769 in modified HS-media until $\mathrm{BC}$ membrane production was observed (14 days). The BC membrane was submitted to purification processes and dried for $24 \mathrm{~h}$, then the pure and dried $\mathrm{BC}$ membrane was exposed to Closite 20A (MMT) to form the BC-MMT biocomposite moisture. The BC-MMT moisture was dried at room temperature for 5 days and characterized in terms of their physical and barrier properties, morphologies, and thermal stabilities.

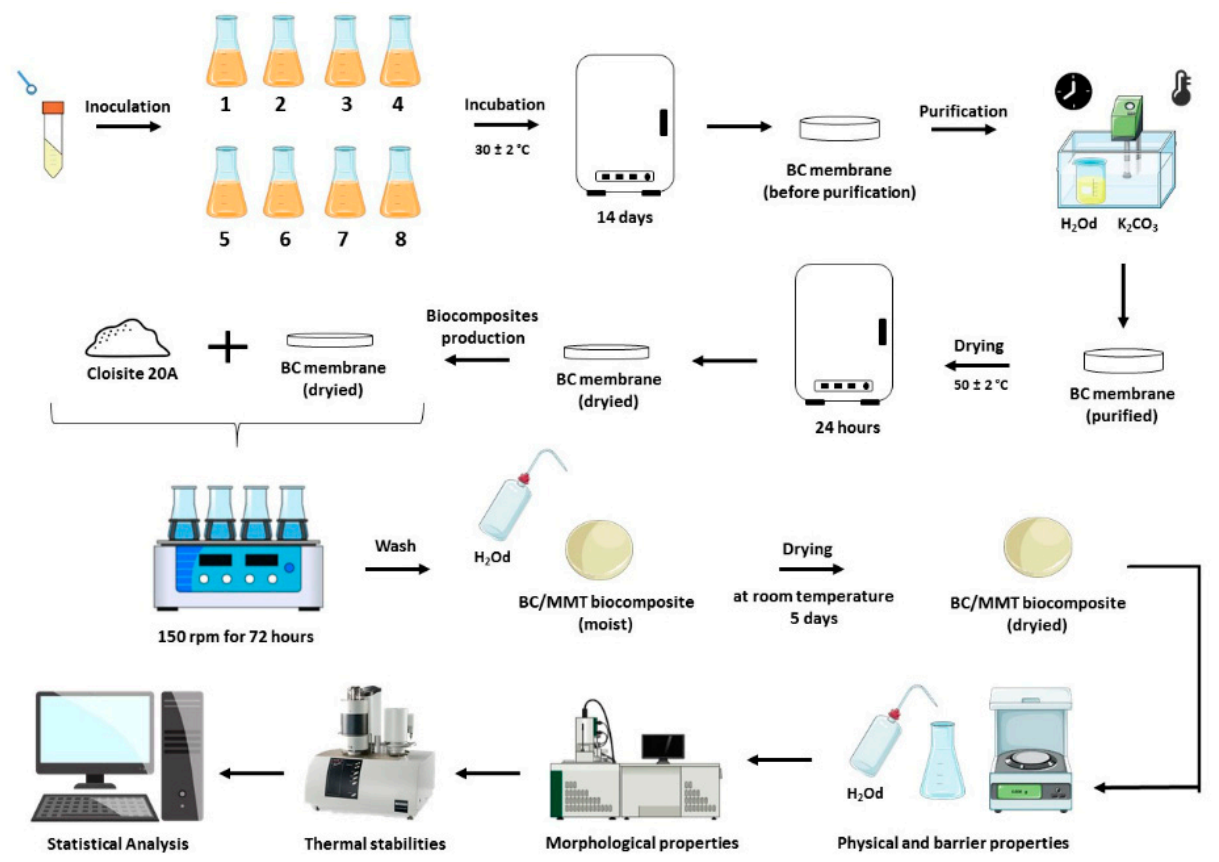

Figure 1. Complete methodology used for BC and BC-MMT biocomposite production and characterization.

\subsection{Bacterial Strain, Culture Media and Production Kinetics}

The G. hansenii strain (ATCC 23769), obtained from the Tropical Culture Collection (CCT)-André Tosello Foundation, was used in the static fermentation process to obtain BC. The culture was grown in modified Hestrin-Schramm (HS) media containing 25 or $50 \mathrm{~g} \cdot \mathrm{L}^{-1}$ carbon source (glucose, mannitol, sucrose, and xylose), $5 \mathrm{~g} \cdot \mathrm{L}^{-1}$ yeast extract, $3 \mathrm{~g} \cdot \mathrm{L}^{-1}$ peptone, and $2 \mathrm{~g} \cdot \mathrm{L}^{-1} \mathrm{KH}_{2} \mathrm{PO}_{4}$ (Table 1). All the culture media were sterilized $\left(121^{\circ} \mathrm{C}, 15 \mathrm{~min}\right)$ and incubated at $30^{\circ} \mathrm{C}$ for 14 days. $\mathrm{BC}$ production kinetics were evaluated $\left(\mathrm{OD}_{600}\right)$ until $\mathrm{BC}$ production was observed.

\subsection{BC Purification, Yield Calculation and Dry Film Formation}

$\mathrm{BC}$ membranes were purified by alkaline treatment with potassium carbonate $\left(\mathrm{K}_{2} \mathrm{CO}_{3}\right)$. The membranes were washed twice with distilled water at $80^{\circ} \mathrm{C}$ for $1 \mathrm{~h}$ to remove impurities from the culture medium. Then, the membranes were treated with $0.3 \mathrm{~mol} \cdot \mathrm{L}^{-1} \mathrm{~K}_{2} \mathrm{CO}_{3}$ aqueous solution at $80^{\circ} \mathrm{C}$ for $1 \mathrm{~h}$ and washed with distilled water until a neutral $\mathrm{pH}$ was obtained. The purified $\mathrm{BC}$ membranes were dried at $50{ }^{\circ} \mathrm{C}$ for $24 \mathrm{~h}$ and weighed before and after drying. 
Table 1. Media components and concentration.

\begin{tabular}{ccccccccc}
\hline \multirow{2}{*}{$\begin{array}{c}\text { Medium } \\
\text { Components }\end{array}$} & \multicolumn{7}{c}{ Culture Medium $(\%, w / v)$} \\
\cline { 2 - 9 } & $\mathbf{1}$ & $\mathbf{2}$ & $\mathbf{3}$ & $\mathbf{4}$ & $\mathbf{5}$ & $\mathbf{6}$ & $\mathbf{7}$ & $\mathbf{8}$ \\
\hline Glucose & 25.0 & 50.0 & - & - & - & - & - & - \\
Mannitol & - & - & 25.0 & 50.0 & - & - & - & - \\
Sucrose & - & - & - & - & 25.0 & 50.0 & - & - \\
Xylose & - & - & - & - & - & - & 25.0 & 50.0 \\
Peptone & 3.0 & 3.0 & 3.0 & 3.0 & 3.0 & 3.0 & 3.0 & 3.0 \\
Yeast extract & 5.0 & 5.0 & 5.0 & 5.0 & 5.0 & 5.0 & 5.0 & 5.0 \\
$\mathrm{KH}_{2} \mathrm{PO}_{4}$ & 2.0 & 2.0 & 2.0 & 2.0 & 2.0 & 2.0 & 2.0 & 2.0 \\
\hline
\end{tabular}

Legend Table 1: (-) Not added.

\subsection{Preparation of the BC-MMT Biocomposites}

The BC-MMT biocomposites were produced as previously described by Perotti et al. [19]. MMT (Cloisite 20A) was vigorously crushed in a crusher (Turratec TE-102) for $10 \mathrm{~min}$ to produce a homogeneous suspension with smaller particles. The BC-MMT nanocomposites were prepared by mixing BC and MMT suspensions in a mechanical shaker at $150 \mathrm{rpm}$ for $72 \mathrm{~h}$. The biocomposites were removed from the beakers, washed with deionized water and dried at room temperature for 5 days. The MMT proportions in the BC-MMT composites were $0.5,1.0$ and $2.0 \%$; the samples were labeled as bacterial cellulose BC (sample without MMT), BC-MMT0.5, BC-MMT1, and BC-MMT2, respectively (Table 2).

Table 2. Sample name and montmorillonite (MMT) concentration of biocomposites.

\begin{tabular}{cc}
\hline Sample Name & MMT Concentration (\%) \\
\hline BC & 0.0 \\
BC-MMT0.5 & 0.5 \\
BC-MMT1 & 1.0 \\
BC-MMT2 & 2.0 \\
\hline
\end{tabular}

\section{4. $B C$ and BC-MMT Biocomposite Characterization}

\subsubsection{Water Activity and Water Absorption Capacity}

The measurements of water activity $\left(\mathrm{a}_{\mathrm{w}}\right)$ were performed using a Decagon (Novasina, Lab Master $\mathrm{a}_{\mathrm{w}}$, Switzerland) at a temperature of $25^{\circ} \mathrm{C}$. The equipment software applied an equation to evaluate the "actual balance" $\left[\mathrm{a}_{\mathrm{w}}=\right.$ moisture in the balance sheet $=$ actual balance $\left.(\%) / 100\right]$ [42]. The analyses were performed in triplicate.

The water absorption capacity (WAC) of the membranes (biocomposites) was assessed using 1.5 -cm-diameter samples. The initial dry mass was obtained after drying at $50^{\circ} \mathrm{C} \pm 2{ }^{\circ} \mathrm{C}$ for $2 \mathrm{~h}$. The specimens were immersed in $50 \mathrm{~mL}$ of distilled water for 2, 24, 48, 66 and $72 \mathrm{~h}$. After the predetermined intervals, the specimens were removed, and the excess water was absorbed on filter paper for $1 \mathrm{~min}$. The hydrated films were reassessed. The rehydration rate was calculated according to Equation (1):

$$
\text { WAC }=(\text { water mass removed along drying }(\mathrm{g})) /(\text { dried mass of the sample }(\mathrm{g}))
$$

\subsubsection{Grammage and Thickness}

Grammage was determined according to Almeida et al. [43]. A 2- $\mathrm{cm}^{2}$ area of each film was weighed on an analytical balance to determine sample mass. The weight was calculated as the ratio between the mass found and the area. The analyses were performed in triplicate. The thickness of the films was evaluated by analyzing the mean thickness of ten measurements at random positions of 
each respective formulation using a flat point digital micrometer (Digimess; Ip40, São Paulo, Brazil; 0.001-mm resolution).

\subsubsection{Water Holding Capacity and Water Release Rate}

The ability of the films to conserve water was evaluated by the water holding capacity (WHC) according to Schrecker and Gostomski with adaptations [44]. The membranes were cut into circular specimens $\left(2 \mathrm{~cm}^{2}\right.$ in diameter), and their initial dry weight (Pd) was measured. Then, the membranes were immersed in deionized water for $48 \mathrm{~h}$. The swollen membranes were then rapidly dried with filter paper to remove excess surface water and placed in open Petri dishes at room temperature. The membranes were removed from the plates every $24 \mathrm{~h}$ to be weighed $(\mathrm{Pm})$ with a total analysis time of $96 \mathrm{~h}$. The WHC was defined by Pm divided by Pd. To determine the water release rate (WRR), the wet masses of the samples were measured following continuous weighing of the samples stored under ambient conditions at different time intervals until a constant mass was obtained. The mass obtained at different time intervals was expressed as a function of time [21]. The WHC and WRR analyses were performed in triplicate.

\subsubsection{Thermogravimetric Analysis (TGA)}

Thermogravimetric analysis (TGA) was carried out on a Q50 thermogravimetric analyzer (TA instruments, Bavaria, Germany). For this analysis, approximately $8 \mathrm{mg}$ of each sample was placed in a platinum crucible at a heating rate of $10{ }^{\circ} \mathrm{C} \mathrm{min}-1$ from $25^{\circ} \mathrm{C}$ to $1000{ }^{\circ} \mathrm{C}$ under a nitrogen flow $(30 \mathrm{~mL}$ $\min ^{-1}$ ), according to Machado et al. [45]. Differential thermogravimetry (DTG) curves were calculated from the TGA results.

\subsubsection{Scanning Electron Microscopy (SEM)}

Scanning electron microscopy (SEM) (BX-51; Olympus, Tokyo, Japan) was used to study the surface morphology and elements of the nanocomposites. The samples were manually fixed using tweezers (PELCO1 Tweezers) with aluminum metal surfaces covered with carbon double-sided tape, called stubs, according to that previously described by Machado et al. [46]. Due to the need for interaction of the electron beam with the samples, the method was performed by coating deposition of metallic gold ions (sputtering). The samples were metalized in gold in a "Sputter oater" from Balzers (SCD 50; BAL-TEC, Grand Island, NY, USA). Then, the stubs containing the metallic samples were stored in plastic boxes (storage boxes) and double sealed with Parafilm (PARAFILM1 M) to prevent moisture absorption. The samples were analyzed at different magnifications (Voltage $12 \mathrm{kV}$, Working Distance $12 \mathrm{~mm}$, Spot size 44, Vacuum Mode HV).

\subsection{Statistical Analysis}

The results are expressed as the mean \pm standard deviation $(n=3)$. For the statistical analysis, the program Statistica 6.0 from StatSoft (Tulsa, OK, USA) was used. Analysis of variance and Tukey's test were used to identify significant differences between the means $(p<0.05)$ of the investigated parameters.

\subsection{Experimental Program}

Table 3 shows the experimental program of the study, with the analyzed specimens, the tests performed and their respective parameters. 
Table 3. Experimental program of pure BC and BC-MMT biocomposite analysis.

\begin{tabular}{ccccc}
\hline \multirow{2}{*}{ Specimen } & MMT & \multicolumn{3}{c}{ Test Types } \\
\cline { 3 - 5 } & Concentration (\%) & Physical/Barriers & Morphological & Thermal \\
\cline { 3 - 5 } BC & 0.0 & Water Activity Water Absorption Capacity & & \\
BC-MMT0.5 & 0.5 & Grammage Thickness & Scanning Electron & Thermogravimetric \\
BC-MMT1 & 1.0 & Water Holding Capacity & Microscopy & Analysis \\
BC-MMT2 & 2.0 & Water Release Rate & & \\
\hline
\end{tabular}

\section{Results and Discussion}

\subsection{Effect of Different Carbon Sources on Cellulose Yields}

Due to its unique properties, $\mathrm{BC}$ has drawn attention from industries exploring novel strategies for improving BC production. Unfortunately, large-scale production and industrialization of BC are limited due to the low-cost effectiveness of cultivation in traditional synthetic media and static cultures. As a result, numerous efforts have been made to develop new methods for BC production. As described in different studies, BC production can be greatly influenced by a range of variants, such as bacterial strain, reactor type, $\mathrm{pH}$, temperature, aerobic conditions, and nutrient concentration in the culture media [39,40,47-50]. Among these nutrients, the influence of the carbon sources has been the object of continuous studies [49,50]. The present study highlights the ability of G. hansenii ATCC 23769 to metabolize several carbon sources in modified HS media and the effects on cellulose production. The bacteria were incubated for 14 days, which is the time until the first BC production was observed, and cellulose was extracted to examine the yields. Figure 2 shows the bacterial growth over time.

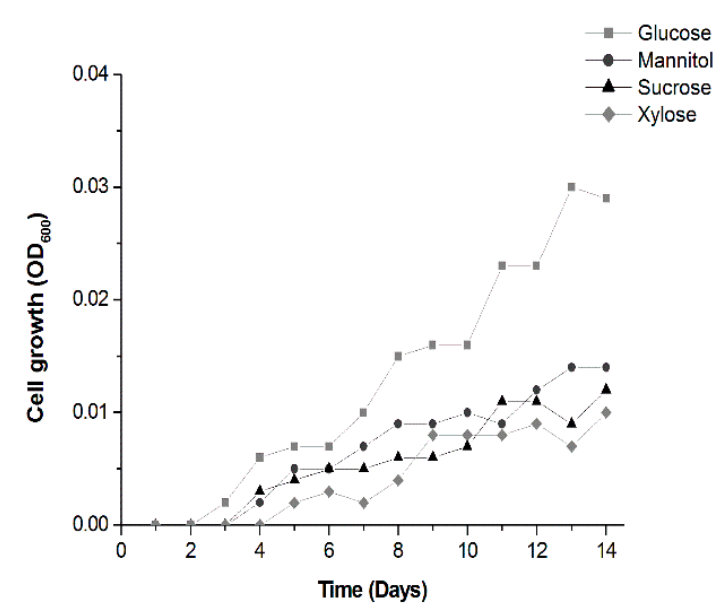

(a)

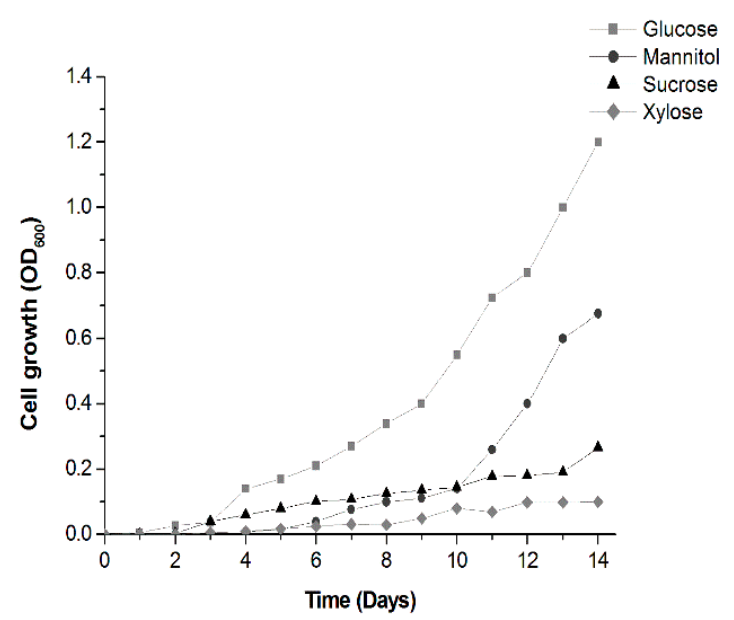

(b)

Figure 2. Effect of different carbon sources at $25 \mathrm{~g} \cdot \mathrm{L}^{-1}$ (a) and $50 \mathrm{~g} \cdot \mathrm{L}^{-1}$ (b) concentrations on bacterial growth over time. BC was fermented by static culture for a 14-day period.

Bacterial growth was observed in all media as expected, since G. hansenii is able to assimilate various sugars $[37,47,51]$. However, better growth (optical density, $\mathrm{OD}_{600}$ ) was observed in media with higher carbon concentrations, especially glucose-containing media (Figure $2 b$ ). The results are in agreement with other findings demonstrating that G. hansenii exhibits better growth than other Gluconacetobacter species in glucose-containing media due to its ability to direct its energy towards cell growth instead of polysaccharide production [52,53].

Regarding BC production, BC yields were observed starting on day 14 only in media with glucose in $50 \mathrm{~g} \cdot \mathrm{L}^{-1}$ concentration (14.72 $\mathrm{g}$ of purified BC) (Figure 3). Media containing mannitol at the same concentration produced BC yields only after 20 days of incubation. BC yields were not observed in media containing sucrose and xylitol as carbon sources at the pre-established concentrations. BC is a 
biopolymer produced from hexose phosphate generated by phosphorylated exogenous hexoses or indirectly via the pentose cycle and gluconeogenic pathway [54].

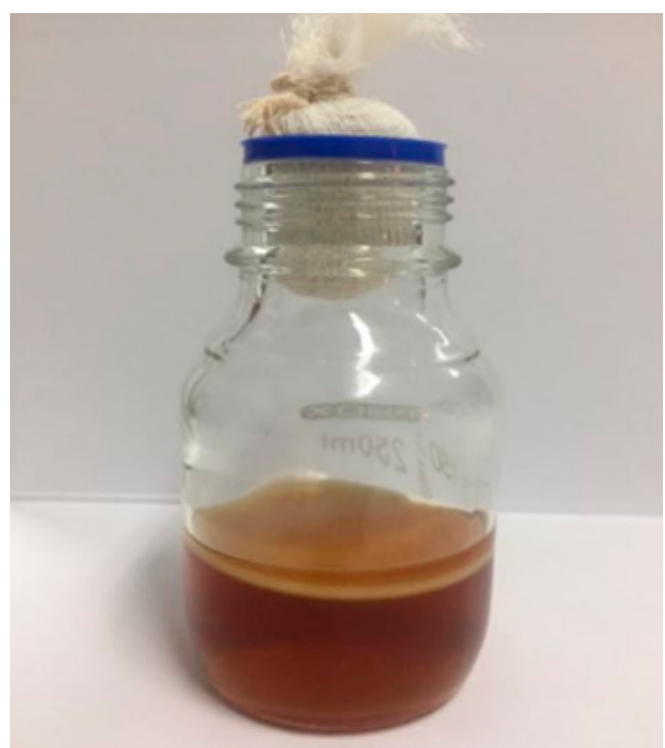

(a)

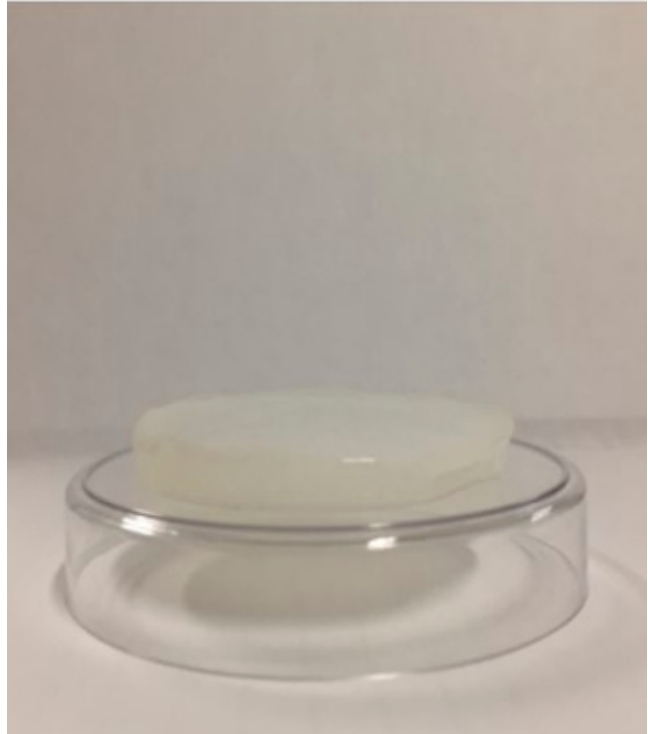

(b)

Figure 3. BC produced by G. hansenii: (a) BC produced in glucose-containing media after a 14-day incubation period; (b) pure BC membrane after purification process.

Four sugars were used in this study: glucose, mannitol, sucrose, and xylose. Only glucose and mannitol are hexose sugars and produced cellulose yields. The results are consistent with the observations by Rani et al., Molina-Ramírez, and others $[41,55,56]$, who indicated that BC production is affected by carbon source type and concentration (Table 4 ).

Table 4. Comparison of reports of BC production by G. hansenii in various media.

\begin{tabular}{|c|c|c|c|c|c|}
\hline Microorganism & Carbon Source & Supplementary Materials & $\begin{array}{l}\text { Culture Time } \\
\text { (Days) }\end{array}$ & $\begin{array}{l}\text { Culture } \\
\text { Method }\end{array}$ & Reference \\
\hline G. hansenii ATCC 23769 & Fructose & Glacial acetic acid & 7 & Static & [57] \\
\hline G. hansenii ATCC 23769 & Glucose & - & 10 & Static & [58] \\
\hline G. hansenii ATCC 23769 & Glucose & Galactose & 7 & - & [59] \\
\hline G. hansenii ATCC 23769 & Glucose & $\begin{array}{c}\text { Cellulose nanofibril } \\
\text { Nanoclay } \\
\text { xGnP }\end{array}$ & 9 & Static/Agitated & [60] \\
\hline G. hansenii ATCC 23769 & Mannitol & $\begin{array}{l}\text { D-(+)-glucose } \\
\text { Dextrin }\end{array}$ & 7 & Static & [61] \\
\hline G. hansenii ATCC 23769 & Glucose & - & 5 & Static & {$[62]$} \\
\hline G. hansenii ATCC 23769 & Mannitol & - & 14 & Agitated & {$[63]$} \\
\hline G. hansenii NCIM 2529 & $\begin{array}{l}\text { Sucrose } \\
\text { Glucose }\end{array}$ & $\mathrm{CaCl}_{2}$ & 5 & Agitated & [64] \\
\hline G. hansenii UCP 1619 & $\begin{array}{l}\text { Acetylated } \\
\text { glucose } \\
\text { Molasses }\end{array}$ & Corn steep liquor & 10 & Static & [65] \\
\hline G. hansenii CGMCC 3917 & Glucose & $\begin{array}{c}\text { Hydrolysate of waste beer } \\
\text { yeast }\end{array}$ & 10 & Static & [66] \\
\hline
\end{tabular}

Hutchens et al. [67] evaluated the effects of glucose and mannitol on BC production by G. hansenii. In that work, the $\mathrm{BC}$ membranes started to appear after 22 days of fermentation. However, these findings show that bacteria produced higher BC yields in mannitol-containing media. Rukka et al. [47] reported similar results comparing media containing glucose, mannitol, and fructose for $\mathrm{BC}$ production. In a 7-day G. xylinus fermentation period, those findings reveal glucose and mannitol as better carbon sources; however, bacteria produced more BC in mannitol-containing media with 13.5 and $16 \mathrm{mg}$ of cellulose mass production. In a comparative study, Kawano et al. [52] demonstrated that G. hansenii 
presented a twice the growth of G. xylinum, while the cellulose synthesis by G. xylinum was higher in glucose-containing media; these findings suggest that $G$. hansenii directs its energy towards cell growth, while G. xylinum spends its energy on BC production. The difference in BC production using different carbon sources by Gluconacetobacter strains is probably because these species have a major number of glucose metabolic pathways to transform glucose into energy for general activities through oxidative metabolism [54]. It is important to mention that there are other factors in addition to carbon sources that influence $\mathrm{BC}$ production, such as media $\mathrm{pH}$, nitrogen source, temperature and static or shacking conditions, which are crucial for process optimization $[50,55,68]$.

Our work demonstrates that in modified HS media, G. hansenii ATCC 23769 produces higher $\mathrm{BC}$ yields in glucose-containing media. An interesting fact is that sucrose and xylose did not lead to any $\mathrm{BC}$ production. Since sucrose is a disaccharide composed of two hexose sugars (glucose and fructose), $\mathrm{BC}$ synthesis using this sugar requires an additional metabolic step to catalyze the sucrose into glucose and fructose to achieve cellulose production, but greater than 14 days of incubation are required to start producing BC [68]. Molina-Ramírez et al. and Ruka et al. [47,56] have reported low levels of cellulose after an initial incubation period followed by high levels after some days, indicating an increased lag period for cellulose production. In contrast to hexoses, xylose is a poor carbon source for cellulose production by Gluconacetobacter species. Ishihara et al. [69] have reported that G. xylinus oxides d-xylose to $\mathrm{d}$-xylonic acid, which causes very low $\mathrm{pH}$ conditions that are unfavorable for bacterial growth and cellulose production. In this work, xylose would become a utilizable substrate for bacterial strains if xylose-isomerase was added to the medium.

\subsection{Effect of Different MMT Concentrations on BC Properties}

As previously described, the BC produced was used to develop BC-MMT biocomposites. Flexible membrane formulations of BC-MMT biocomposites were evaluated based on the following features: physical properties (grammage, thickness, $\mathrm{a}_{\mathrm{W}}$, and water absorption), barrier properties (WHC and WRR), TGA, and morphological properties (SEM) (Table 5, Figures 4-6).

Pure BC exhibited an $\mathrm{a}_{\mathrm{w}}$ value of 0.479 with significant differences $(p<0.05)$ compared with the BC-MMT formulations, which presented higher values ranging from 0.516 to 0.529 (Figure $4 \mathrm{a}$ ). Moreover, a slight decrease in the $\mathrm{a}_{\mathrm{w}}$ values was noted in the samples with higher MMT concentrations. The interactions formed in the BC-MMT composite caused an increase in the free water content. In this case, the presence of MMT potentially significantly contributed to this finding. This notion can be justified because if clay is lacking in the formulation, the bonds between the polymers are stronger. Therefore, there is less water available. This fact directly influences the mechanical properties of the materials, since the main functional properties (mechanical and barrier properties) of these hydrophilic materials depend on their water content, as previously described in other studies [42,70]. Several studies have demonstrated that MMT influences the $\mathrm{a}_{\mathrm{w}}$ in films [71-73]; however, Azevedo et al. [73] reported that the free water in whey protein isolate films decreased when MMT is incorporated, and only one sample presented higher $\mathrm{a}_{\mathrm{w}}$ values compared with other samples.

Table 5. Physical and barrier properties of flexible formulations of pure BC and BC-MMT composites. No significant difference between values with the same superscript letter ${ }^{(a, b, c)}$ in a column $(p>0.05)$, according to Tukey's test with $95 \%$ confidence.

\begin{tabular}{|c|c|c|c|c|}
\hline Sample & Water activity & $\begin{array}{c}\text { Grammage } \\
\left(\mathrm{g} \mathrm{m}^{-2}\right)\end{array}$ & $\begin{array}{l}\text { Thickness } \\
\text { (mm) }\end{array}$ & 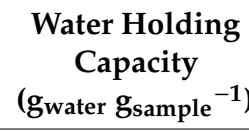 \\
\hline $\mathrm{BC}$ & $0.479^{b} \pm 0.002$ & $0.047^{c} \pm 0.005$ & $81.250^{C} \pm 11.242$ & $87.729^{\mathrm{a}} \pm 4.032$ \\
\hline ВС-ММТ0.5 & $0.529^{\mathrm{a}} \pm 0.002$ & $0.113^{b} \pm 0.016$ & $133.667^{\mathrm{b}} \pm 15.462$ & $46.023^{b} \pm 3.497$ \\
\hline BC-MMT1 & $0.519^{\mathrm{a}} \pm 0.006$ & $0.153^{\mathrm{ab}} \pm 0.045$ & $145.667^{b} \pm 8.221$ & $34.550 \mathrm{~b}^{\mathrm{c}} \pm 3.930$ \\
\hline BC-MMT2 & $0.516^{\mathrm{a}} \pm 0.002$ & $0.209^{\mathrm{a}} \pm 0.054$ & $162.333^{\mathrm{a}} \pm 2.571$ & $29.514^{c} \pm 7.165$ \\
\hline
\end{tabular}




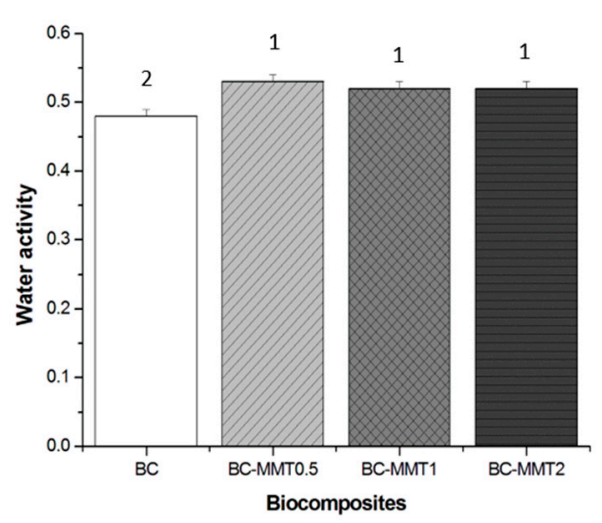

(a)

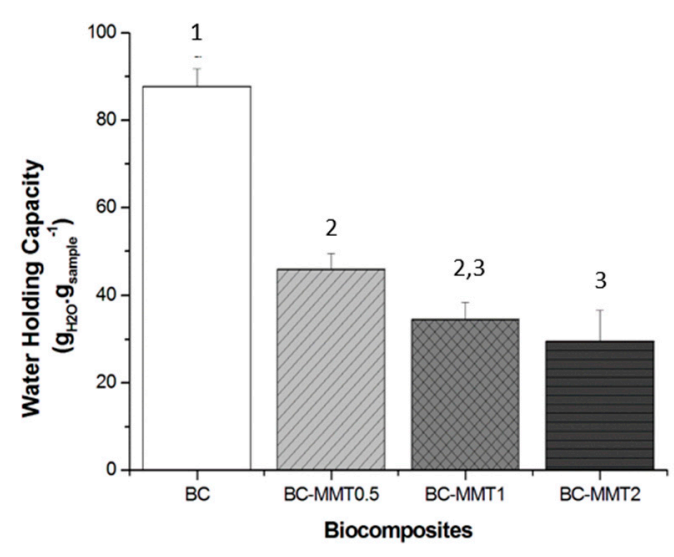

(c)

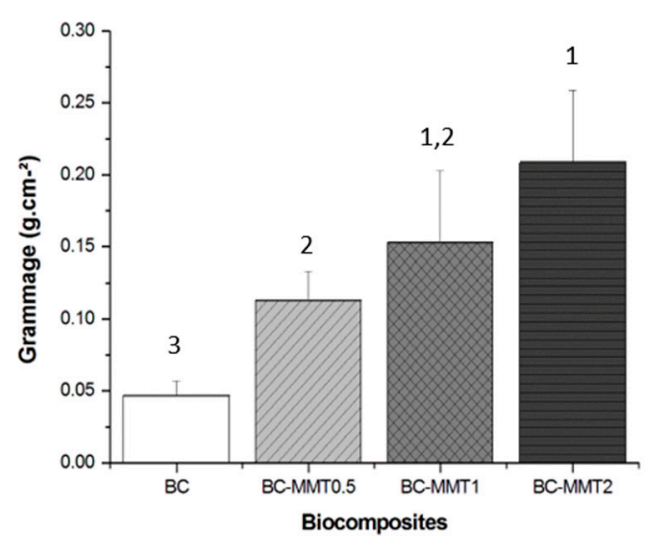

(e)

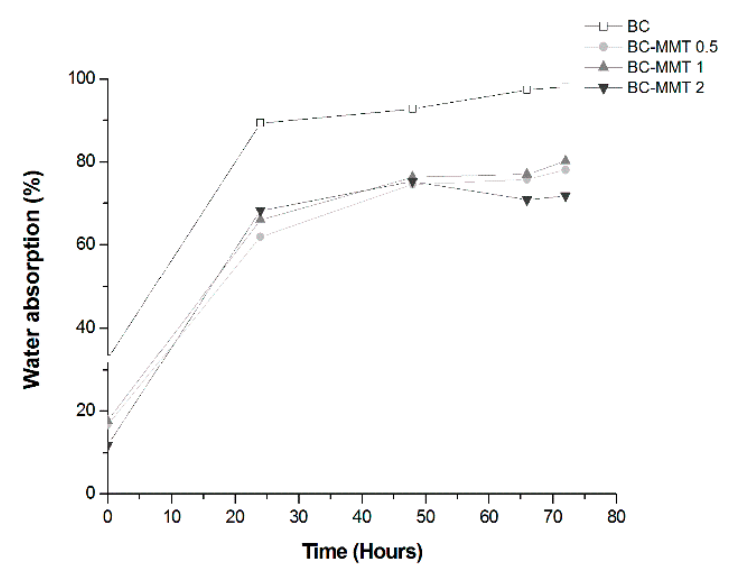

(b)

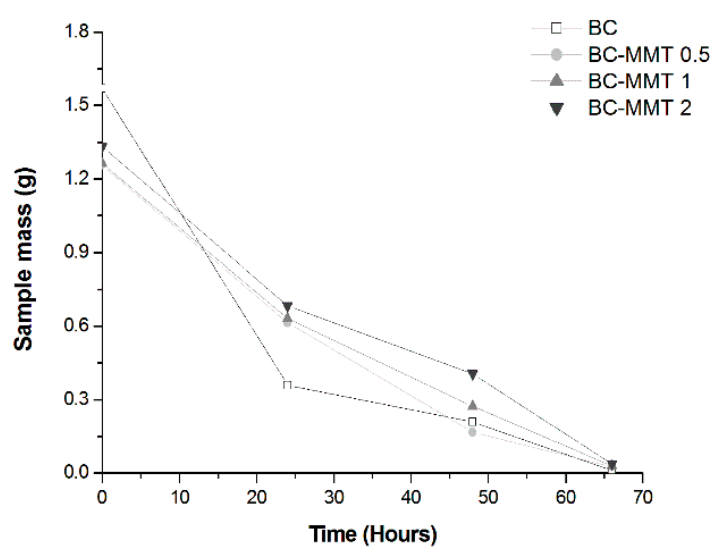

(d)

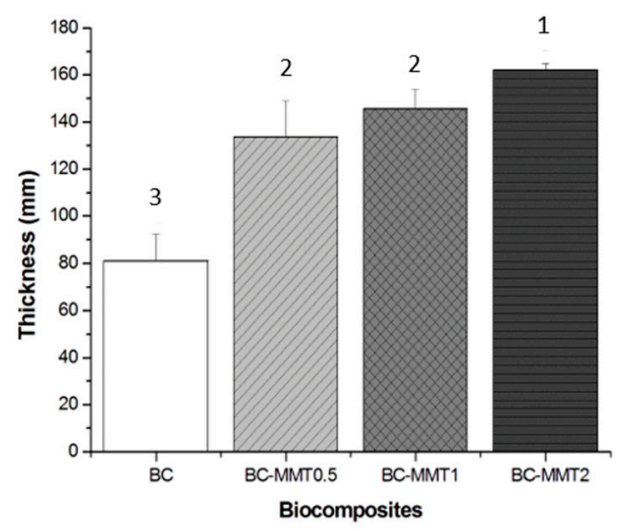

(f)

Figure 4. Physical and barrier properties: (a) Water activity $\left(\mathrm{a}_{\mathrm{w}}\right)$ content; (b) Water absorption; (c) Water holding capacity (WHC); (d) Water release test (WRR); (e) Grammage; and (f) Thickness of pure BC and BC-MMT biocomposites. No significant difference between values with the same superscript numbers $(1,2,3)$ in a bar $(p>0.05)$, according to Tukey's test with $95 \%$ confidence. 


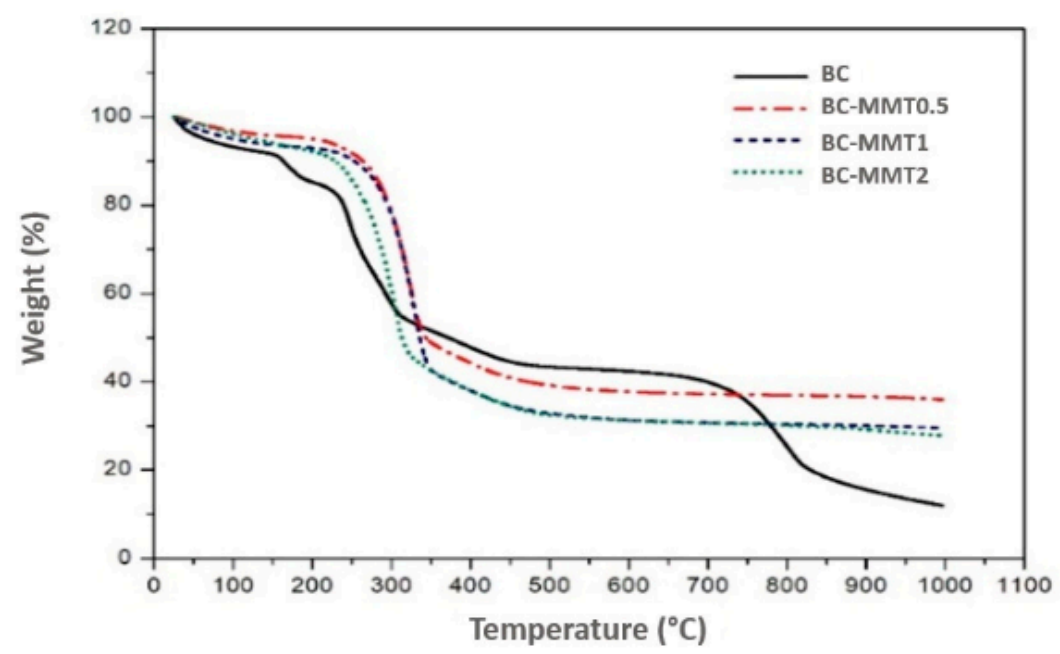

Figure 5. Thermogravimetric analysis (TGA) curves for BC and BC-MMT composites. The composites (BC-MMT1, BC-MMT2 and BC-MMT3) were prepared by impregnation of BC sheets in respective concentrations $(0.5,1$ and $2 \%)$ of MMT suspensions.
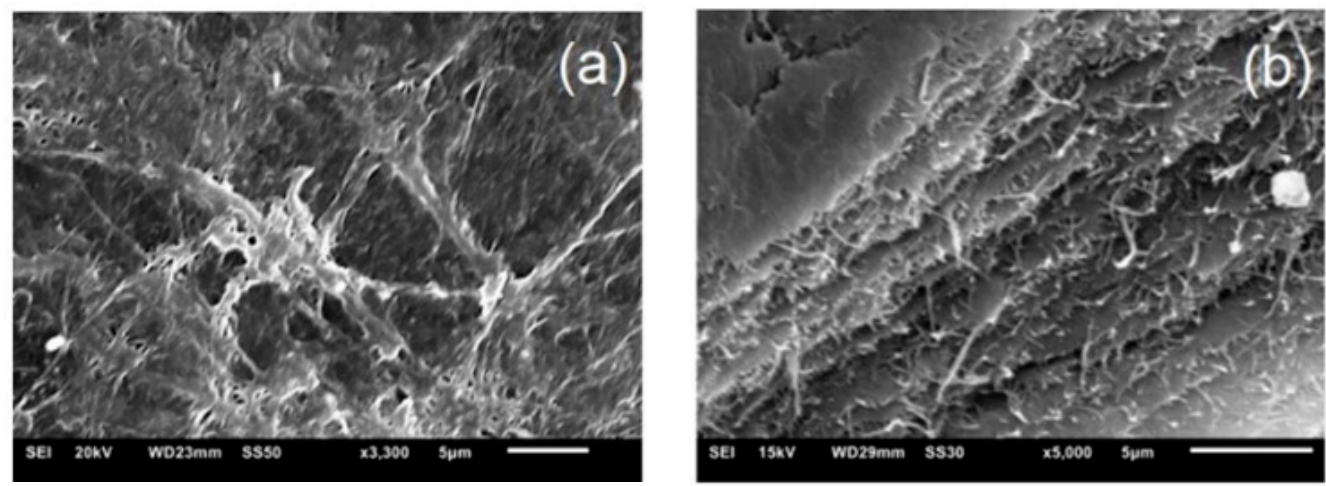

Figure 6. Scanning electron microscopy (SEM) micrographs of the surface and cross-section morphology of pure BC: (a) 3300×; (b) 5000×.

Currently, advanced approaches to wound healing have attracted great attention for the use of novel types of dressing that provide a moist environment to the wound area [74]. This property encourages fast and effective healing, which is particularly important when dealing with chronic wounds $[8,23]$. Moreover, a moist environment facilitates the penetration of active substances and potentially allows for an easy and painless dressing change, protecting the newly formed skin from damage. Due to its physical and barrier properties, such as a high WHC and slow WRR, BC has been extensively studied for use as a wound dressing material $[15,21,28]$. Therefore, in this study, we investigated the WAC, WHC, and WRR of the pure BC and the BC-MMT composites for use in wound dressing applications.

Our results show that the WAC of pure BC increased compared with that of the BC-MMT composites (Figure $4 \mathrm{~b}$ ). The samples of pure BC recovered approximately $90 \%$ of their dry mass in $72 \mathrm{~h}$ of water immersion, while the hybrid materials recovered approximately $80 \%$. The deposition of MMT particles on the surface and in the matrix of the BC sheets reduces the empty spaces in the BC-MMT composites, which ultimately results in the lower water absorption and lower WHC of the composites. The MMT absorption and penetration inside the $\mathrm{BC}$ matrix increases with the MMT concentration, which subsequently results in decreased WHC in the following order, BC $>$ BC-MMT0.5 $>$ BC-MMT1 > BC-MMT2, as shown in Table 5 and Figure 4c. This finding may be explained by the fact that the clay affects the swelling capacity of the material [31]. Any coefficient that reduces the empty spaces between the layers or pores will directly affect this mechanism. Similar results were 
obtained by other authors who observed a diminution in the water absorbed by nanocomposites made with MMT [48,75-78]. Taghizadeh et al. [78] investigated the WAC of sodium montmorillonite clay (MMT-Na) content within cellulose blends. In their work, the blends with MMT-Na content exhibited a significantly reduced WAC rate.

In the present study, the WHC of pure BC was 87.729 , which decreased to $46.023,34.550$ and 29.514 for BC-MMT0.5, BC-MMT1, and BC-MMT2, respectively (Table 5). Since the hydroxyl groups of MMT can form strong hydrogen bonds with the hydroxyl groups on cellulose, the interactions between the molecules and the cohesiveness of biopolymer matrix are improved. In addition, the water sensitivity is reduced. The clay produces a tortuous pathway, and the length of the path for water uptake is reduced [78]. The presence of MMT particles in the matrix of the BC sheets reduces the empty spaces in the BC-MMT composites, thus reducing water absorption and the WHC of the composites [21]. Moreover, Majeed et al. and Bakar et al. [79,80] have demonstrated that composites with MMT possesses improved mechanical properties tensile and flexural strength, important indicators to manufacture qualified wound-dressing material.

Figure $4 \mathrm{~d}$ depicts the WRR values through the variation of sample mass stored under ambient conditions over time. Although the initial content of pure BC is much higher than that found in the BC-MMT biocomposites, there was a drastic reduction, resulting in greater than $80 \%$ water loss in $48 \mathrm{~h}$. The water content in the pure BC was insignificant after $60 \mathrm{~h}$. However, while the initial water content in all the BC-MMT biocomposites was inferior, demonstrating a low WHC, the WRR is gradual and uniform compared to that of the pure BC. The presence of the MMT particles helps to protect the absorbed water molecules from evaporation, leading to its retention for a longer period inside the BC sheets. Ul-Islam et al. [81] reported similar results by evaluating the WHC and WRR of BC obtained by ex situ modification. In that report, it took approximately $90 \mathrm{~h}$ for the complete evaporation of water from the surfaces of composites made with MMT and chitosan. Since the pore size is smaller in these composites (Figure 6), the penetrated water molecules are more tightly sandwiched between the microfibrils.

Figure $4 \mathrm{e}$ shows grammage levels of the pure $\mathrm{BC}$ and $\mathrm{BC}-\mathrm{MMT}$ composites. The pure $\mathrm{BC}$ presented grammage of $81.250 \mathrm{~g} \mathrm{~cm}^{-2}$, while the BC-MMT composites presented levels between 0.113 and 0.209 $\mathrm{g} \mathrm{cm}^{-2}$ in BC-MMT0.5, BC-MMT1, and BC-MMT2 with increases of 39, 44 and 49\%, respectively. The increase in the MMT concentration influenced the grammage property due to increased clay deposits in the polymer matrix. Grammage is directly related to a film's mechanical resistance and barrier properties given that higher grammage levels offer higher mechanical resistance [43]. The mean thickness is another important parameter that must be monitored in films for the maintenance of uniformity, and this parameter allows for the validation of the comparisons of their properties. In this work, the pure BC films presented a thickness of $0.047 \mathrm{~mm}$, while the biocomposites presented higher values of 133.667, 145.667 and $162.333 \mathrm{~mm}$ for BC-MMT0.5, BC-MMT1, and BC-MMT2, respectively. The influence of the nanoclay particles impregnated in $\mathrm{BC}$ grammage and the thickness properties have also been reported by Tunç et al. [77]. That work shows that an increase in the MMT concentration caused an increase in the film thickness and opacity values of methylcellulose films, whereas the increase in the MMT concentration led to a decrease in water adsorption and water solubility.

TGA is a thermal analysis method in which the mass variation of the sample (loss or gain) is determined as a function of temperature and/or time. TGA allows for monitoring the occurrence of various reactions, such as dehydration, oxidation, and degradation. Figure 5 shows the TGA curves (25-1000 $\left.{ }^{\circ} \mathrm{C}\right)$ of the pure BC and BC-MMT composites. The graphs show two major weight loss zones. Approximately $9 \%$ of the mass loss of the pure BC occurs in temperatures between 80 and $120^{\circ} \mathrm{C}$. This finding is in contrast to the BC-MMT materials that presented a mass reduction of only $5 \%$. The weight loss occurring at $80-120^{\circ} \mathrm{C}$ is due to the loss of moisture content and interlayer coordinated water molecules [82]. The relatively higher weight loss for the pure $\mathrm{BC}$ at this temperature range may be due to its higher WHC compared with the BC-MMT composites as shown in Table 5 . In the second phase, degradation of the main cellulose skeleton is initiated at $225^{\circ} \mathrm{C}$ in all samples [82]. 
The maximum weight loss was recorded for all samples during this phase. The weight loss for the pure BC is approximately $45 \%$ during this phase (Figure 5). In this phase, the weight of all the $\mathrm{BC}-\mathrm{MMT}$ composites was lower than that for pure BC. Additionally, with the increased concentration of MMT, the weight loss decreased by approximately 48, 51 and 53\% for BC-MMT0.5, BC-MMT1, and BC-MMT2, respectively. Additionally, Figure 5 shows a difference between the degradation of pure $\mathrm{BC}$ and $\mathrm{BC}-\mathrm{MMT}$ composites along this phase. The first difference is noted at $151{ }^{\circ} \mathrm{C}$ and was extended to $177^{\circ} \mathrm{C}$ for all the formulations.

\subsection{Effect of Different of MMT on Surface Morphology of BC}

Figure 6 shows the SEM images of pure BC and BC-MMT biocomposites. Figure 6a presents a proper fibrous structure of the cellulose produced by G. hansenii and its high porosity [59]. The alkaline treatment performed for BC purification influenced in the porous membrane as evidenced by Sulaeva et al. [8]. The membrane sagittal cut (Figure 6b) presents a porous network interconnected via lamellar formation. Porosity is a characteristic that directly influences the adhesion and cellular growth in the dressing material matrix [83].

From the morphological study of the BC samples immersed in the MMT, it was possible to confirm the syntheses of the BC-MMT biocomposites (Figure 7). BC nanofibrils create an expanded superficial area and a high porous matrix that enables the syntheses of a various composites with nanoparticles [60]. The biocomposites SEM micrographs illustrate the three-dimensional arrangement of microfibrils and MMT penetration in BC layers through its porous structure (Figure 7). MMT is impregnated in the BC superficies, and the level of impregnation increases as the MMT concentration increases. The empty spaces between the fibrils in BC-MMT0.5 (Figure 6a) were almost all filled in BC-MMT2 (Figure 7c) due to the increase in particle accumulation. Moreover, the MMT particle size seems to be higher in BC-MMT2. This result could be explained by the particle's agglomeration in the matrix.
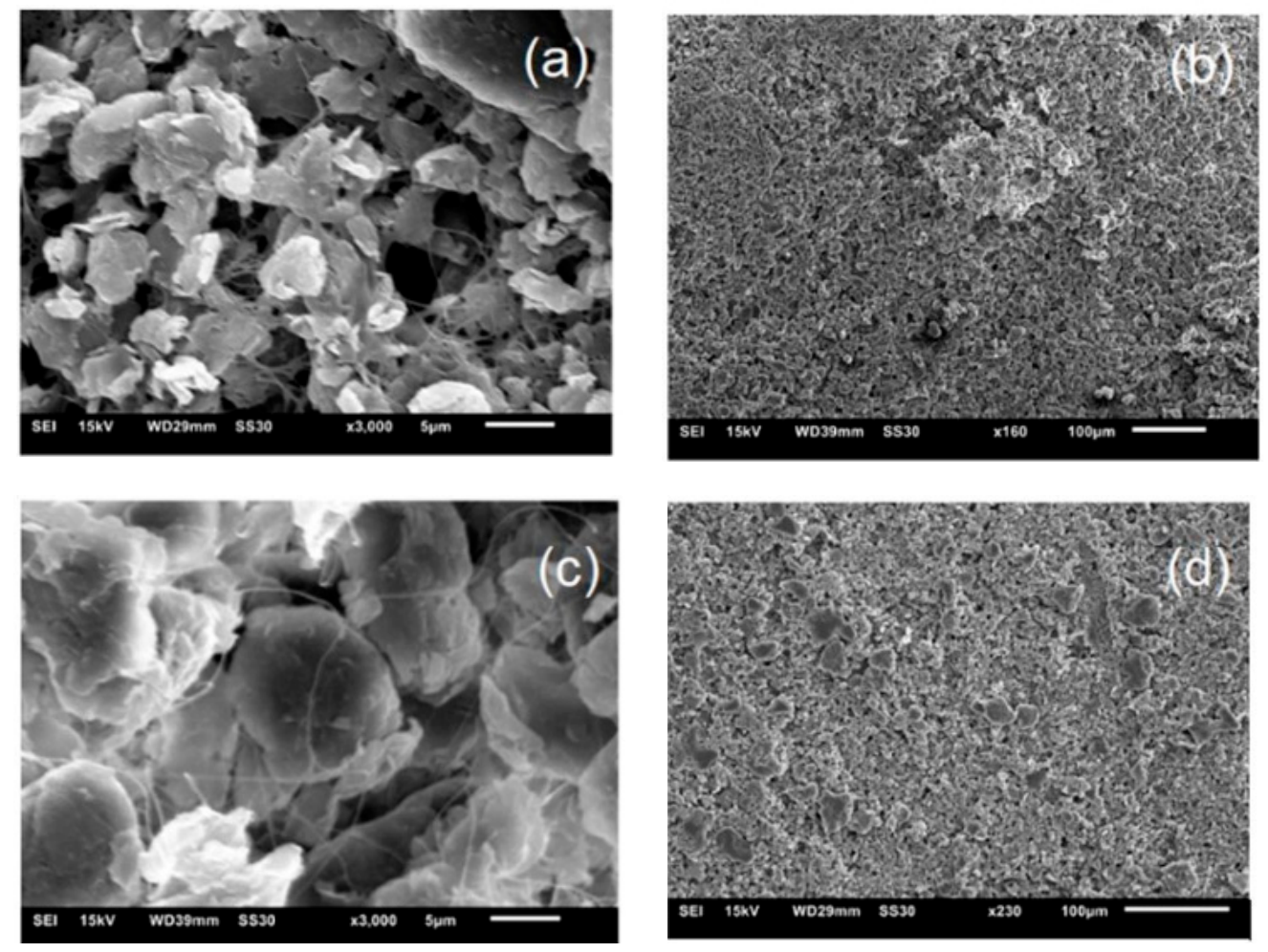

Figure 7. Scanning electron microscopy (SEM) micrographs of the surface and cross section morphology of: $(\mathbf{a}) \times 3000$ and $(\mathbf{b}) \times 160$ BC-MMT0.5; (c) $\times 3000$ and $(\mathbf{d}) \times 230$ BC-MMT2. 


\section{Conclusions}

In this work, BC production by G. hansenii ATCC 23769 was evaluated using four different carbon sources at two different concentrations $\left(25 \mathrm{~g} \cdot \mathrm{L}^{-1}\right.$ and $\left.50 \mathrm{~g} \cdot \mathrm{L}^{-1}\right)$. The $\mathrm{BC}$ produced was used to synthesize BC-MMT biocomposites for wound dressing applications. The only production yield was obtained in medium with glucose as a carbon source at $50 \mathrm{~g} \cdot \mathrm{L}^{-1}$ concentrations. The BC-MMT composites were prepared through a simple particle impregnation strategy to enhance the physico-mechanical properties of BC. Various analytical techniques, including $a_{w}, W A C, W H C, W R R$, grammage, thickness and TGA, were used to characterize the composites. It was observed a slight increase in the $\mathrm{a}_{\mathrm{w}}$ values in the samples with higher MMT concentrations, from 0.529 to 0.516 . The WAC of pure BC increased compared with that of the BC-MMT composites while the WHC decreased with higher MMT concentrations from 46.023 to $29.514 \mathrm{~g}_{\text {water }} \mathrm{g}_{\text {sample }}{ }^{-1}$. Regarding grammage, the pure BC presented $81.250 \mathrm{~g} \mathrm{~cm}^{-2}$, while the BC-MMT composites presented levels between 0.113 and $0.209 \mathrm{~g} \mathrm{~cm}^{-2}$. The pure $B C$ films presented a thickness of $0.047 \mathrm{~mm}$, while the biocomposites presented higher values of 133.667, 145.667, and $162.333 \mathrm{~mm}$ in higher MMT concentrations. These results show that the physical-mechanical and thermal properties of the composites were significantly improved compared to those of pure BC. Additionally, the BC-MMT composite exhibited improvements in the WRR compared with that of the pure $\mathrm{BC}$. This is an important feature of $\mathrm{BC}$ in wound dressing applications. For industrial applications of $\mathrm{BC}$, it is important to find cost-effectiveness conditions. Additionally, the addition of materials, such as MMT, enhances BC properties for biomedical applications. The results reported in this study support the production of $B C$ with good yield while using glucose as carbon source and the composites produced from this polymer with MMT showed interesting results for further analysis of their properties, aiming at their application as wound dressing.

Author Contributions: Conceptualization, J.D.V.B. and B.A.S.M.; Data curation, K.V.S.H., I.M.d.S.S., J.C.C., R.E.d.S.-J. and B.A.S.M.; Formal analysis, K.V.S.H., L.M.d.S.F., I.M.d.S.S., J.C.C. and R.E.d.S.-J.; Funding acquisition, B.A.S.M.; Investigation, S.B.N. and J.D.V.B.; Methodology, K.V.S.H., I.M.d.S.S., J.C.C., R.E.d.S.-J. and B.A.S.M.; Project administration, S.B.N. and B.A.S.M.; Resources, J.D.V.B.; Software, S.B.N.; Supervision, J.D.V.B. and B.A.S.M.; Validation, B.A.S.M.; Writing-original draft, K.V.S.H., L.M.d.S.F., S.B.N., J.D.V.B. and B.A.S.M. All authors have read and agreed to the published version of the manuscript.

Funding: This research was funded by FAPESB (Fundação de Amparo à Pesquisa do Estado da Bahia) and SENAI CIMATEC (Campus Integrado de Manufatura e Tecnologia).

Acknowledgments: The authors are grateful to CNPq (Bolsa de Produtividade DT-BASM), FAPESB and SENAI CIMATEC.

Conflicts of Interest: The authors declare no conflict of interest.

\section{References}

1. Shah, N.; Ul-islam, M.; Ahmad, W.; Kon, J. Overview of bacterial cellulose composites: A multipurpose advanced material. Carbohydr. Polym. 2013, 98, 1585-1598. [CrossRef]

2. Shabalkin, I.; Shabalkin, P. New conceptions about structure formation of biopolymers. In Biotechnology of Biopolymers; Elnashar, M., Ed.; IntechOpen: London, UK, 2011; ISBN 978-953-307-179-4.

3. Mondal, S. Preparation, properties and applications of nanocellulosic materials. Carbohydr. Polym. 2017, 163, 301-316. [CrossRef]

4. Qiao, N.; Fan, X.; Zhang, X.; Shi, Y.; Wang, L.; Yu, D. Soybean oil refinery effluent treatment and its utilization for bacterial cellulose production by Gluconacetobacter xylinus. Food Hydrocoll. 2019, 97, 105185. [CrossRef]

5. Cherng, J.; Wang, H.; Wu, S. Bioapplications of bacterial cellulose polymers conjugated with resveratrol for epithelial defect regeneration. Polymers 2019, 11, 1048.

6. Dydak, K.; Junka, A.; Szymczyk, P.; Chodaczek, G.; Toporkiewicz, M.; Fijałkowski, K.; Dudek, B.; Bartoszewicz, M. Development and biological evaluation of Ti6Al7Nb scaffold implants coated with gentamycin-saturated bacterial cellulose biomaterial. PLoS ONE 2018, 13, e0205205. [CrossRef] [PubMed]

7. Gopi, S.; Balakrishnan, P.; Chandradhara, D.; Poovathankandy, D.; Thomas, S. General scenarios of cellulose and its use in the biomedical field. Mater. Today Chem. 2019, 13, 59-78. [CrossRef] 
8. Sulaeva, I.; Henniges, U.; Rosenau, T.; Potthast, A. Bacterial cellulose as a material for wound treatment: Properties and modifications. A review. Biotechnol. Adv. 2015, 33, 1547-1571. [CrossRef] [PubMed]

9. Ye, S.; Jiang, L.; Su, C.; Zhu, Z.; Wen, Y.; Shao, W. Development of gelatin/bacterial cellulose composite sponges as potential natural wound dressings. Int. J. Biol. Macromol. 2019, 133, 148-155. [CrossRef]

10. Savitskaya, I.S.; Shokatayeva, D.H.; Kistaubayeva, A.S.; Ignatova, L.V.; Digel, I.E. Antimicrobial and wound healing properties of a bacterial cellulose based material containing B. subtilis cells. Heliyon 2019, 5, e02592. [CrossRef]

11. Boateng, J.; Catanzano, O. Advanced therapeutic dressings for effective wound healing-A review. J. Pharm. Sci. 2015, 104, 3653-3680. [CrossRef]

12. Chuah, C.; Wang, J.; Tavakoli, J.; Tang, Y. Novel bacterial cellulose-poly (acrylic acid) hybrid hydrogels with controllable antimicrobial ability as dressings for chronic wounds. Polymers 2018, 10, 1323. [CrossRef] [PubMed]

13. Cao, Y.M.; Liu, M.Y.; Xue, Z.W.; Qiu, Y.; Li, J.; Wang, Y.; Wu, Q.K. Surface-structured bacterial cellulose loaded with hUSCs accelerate skin wound healing by promoting angiogenesis in rats. Biochem. Biophys. Res. Commun. 2019, 516, 1167-1174. [CrossRef] [PubMed]

14. Yu, C.-M.; Lien, C.-C. Biocellulose Dressing and Method for Preparing the Same. U.S. Patent 2013/0149368, 13 June 2013.

15. Portela, R.; Leal, C.R.; Pedro, L. Minireview bacterial cellulose: A versatile biopolymer for wound dressing applications. Microb. Biotechnol. 2019, 12, 586-610. [CrossRef] [PubMed]

16. Faisul Aris, F.A.; Mohd Fauzi, F.N.A.; Tong, W.Y.; Syed Abdullah, S.S. Interaction of silver sulfadiazine with bacterial cellulose via ex-situ modification method as an alternative diabetic wound healing. Biocatal. Agric. Biotechnol. 2019, 21, 101332. [CrossRef]

17. Ostadhossein, F.; Mahmoudi, N.; Morales-Cid, G.; Tamjid, E.; Navas-Martos, F.J.; Soriano-Cuadrado, B.; Paniza, J.M.L.; Simchi, A. Development of chitosan/bacterial cellulose composite films containing nanodiamonds as a potential flexible platform for wound dressing. Materials 2015, 8, 6401-6418. [CrossRef]

18. Pang, M.; Huang, Y.; Meng, F.; Zhuang, Y.; Liu, H. Application of bacterial cellulose in skin and bone tissue engineering. Eur. Polym. J. 2019, 122, 109365. [CrossRef]

19. Treesuppharat, W.; Rojanapanthu, P.; Siangsanoh, C.; Manuspiya, H.; Ummartyotin, S. Synthesis and characterization of bacterial cellulose and gelatin-based hydrogel composites for drug-delivery systems. Biotechnol. Rep. 2017, 15, 84-91. [CrossRef]

20. Luo, H.; Ao, H.; Li, G.; Li, W.; Xiong, G.; Zhu, Y. Bacterial cellulose/graphene oxide nanocomposite as a novel drug delivery system. Curr. Appl. Phys. 2017, 17, 249-254. [CrossRef]

21. Ul-islam, M.; Khan, T.; Kon, J. Nanoreinforced bacterial cellulose-Montmorillonite composites for biomedical applications. Carbohydr. Polym. 2012, 89, 1189-1197. [CrossRef]

22. Liu, K.; Catchmark, M. Bacterial cellulose/hyaluronic acid nanocomposites production through co- culturing Gluconacetobacter hansenii and Lactococcus lactis in a two-vessel circulating system. Bioresour. Technol. J. 2019, 290, 121715. [CrossRef]

23. Fu, L.; Zhang, J.; Yang, G. Present status and applications of bacterial cellulose-based materials for skin tissue repair. Carbohydr. Polym. 2013, 92, 1432-1442. [CrossRef] [PubMed]

24. Ye, J.; Guo, L.; Zheng, S.; Feng, Y.; Zhang, T.; Yang, Z. Synthesis of bacterial cellulose based $\mathrm{SnO}_{2}-\mathrm{PPy}$ nanocomposites as potential flexible, highly conductive material. Mater. Lett. 2019, 253, 372-376. [CrossRef]

25. Hosseini, H.; Kokabi, M.; Mohammad, S. Conductive bacterial cellulose/multiwall carbon nanotubes nanocomposite aerogel as a potentially flexible lightweight strain sensor. Carbohydr. Polym. 2018, 201, 228-235. [CrossRef] [PubMed]

26. Dharmalingam, K.; Padmavathi, G.; Kunnumakkara, A.B.; Anandalakshmi, R. Microwave-assisted synthesis of cellulose/zinc-sulfate-calcium-phosphate (ZSCAP) nanocomposites for biomedical applications. Mater. Sci. Eng. C 2019, 100, 535-543. [CrossRef]

27. Li, K.; Jin, S.; Chen, H.; Li, J. Bioinspired interface engineering of gelatin/cellulose nanofibrils nanocomposites with high mechanical performance and antibacterial properties for active packaging. Compos. Part B 2019, 171, 222-234. [CrossRef]

28. Torres, F.G.; Arroyo, J.J.; Troncoso, O.P. Bacterial cellulose nanocomposites: An all-nano type of material. Mater. Sci. Eng. C 2019, 98, 1277-1293. [CrossRef] 
29. Perotti, G.F.; Barud, H.S.; Messaddeq, Y.; Ribeiro, S.J.L.; Constantino, V.R.L. Bacterial cellulose-laponite clay nanocomposites. Polymer 2011, 52, 157-163. [CrossRef]

30. Alves, L.; Ferraz, E.; Gamelas, J.A.F. Composites of nanofibrillated cellulose with clay minerals: A review. Adv. Colloid Interface Sci. 2019, 272, 101994. [CrossRef]

31. Uddin, F. Montmorillonite: An introduction to properties and utilization. In Current Topics in the Utilization of Clay in Industrial and Medical Applications; Zoveidavianpoor, M., Ed.; IntechOpen: London, UK, 2018; ISBN 978-1-78923-729-0.

32. Sajjad, W.; Khan, T.; Ul-islam, M.; Khan, R.; Hussain, Z.; Khalid, A. Development of modified montmorillonite-bacterial cellulose nanocomposites as a novel substitute for burn skin and tissue regeneration. Carbohydr. Polym. 2019, 206, 548-556. [CrossRef]

33. El Bourakadi, K.; Merghoub, N.; Fardioui, M.; El, M.; Mekhzoum, M.; Meftah, I.; Mokhtar, E.; Qaiss, K.; Bouhfid, R. Chitosan/polyvinyl alcohol/thiabendazoluim-montmorillonite bio-nanocomposite films: Mechanical, morphological and antimicrobial properties. Compos. Part B 2019, 172, 103-110. [CrossRef]

34. Ambrogi, V.; Pietrella, D.; Nocchetti, M.; Casagrande, S.; Moretti, V.; De Marco, S.; Ricci, M. Montmorillonite-Chitosan-Chlorhexidine composite films with antibiofilm activity and improved cytotoxicity for wound dressing. J. Colloid Interface Sci. 2017, 491, 265-272. [CrossRef] [PubMed]

35. Kevadiya, B.D.; Rajkumar, S.; Bajaj, H.C.; Shankaran, S.; Gosai, K.; Brahmbhatt, H.; Bhatt, A.S.; Barvaliya, Y.K.; Dave, G.S.; Kothari, R.K. Biodegradable gelatin-Ciprofloxacin-Montmorillonite composite hydrogels for controlled drug release and wound dressing application. Colloids Surf. B Biointerfaces 2014, 122, 175-183. [CrossRef] [PubMed]

36. Wajid, M.; Ul-islam, M.; Khan, S.; Kim, Y.; Kon, J. Innovative production of bio-cellulose using a cell-free system derived from a single cell line. Carbohydr. Polym. 2015, 132, 286-294.

37. Numata, Y.; Kono, H.; Mori, A.; Kishimoto, R.; Tajima, K. Structural and rheological characterization of bacterial cellulose gels obtained from Gluconacetobacter genus. Food Hydrocoll. 2019, 92, 233-239. [CrossRef]

38. Dórame-miranda, R.F.; Gámez-meza, N.; Medina-juárez, L.Á.; Ezquerra-brauer, J.M. Bacterial cellulose production by Gluconacetobacter entanii using pecan nutshell as carbon source and its chemical functionalization. Carbohydr. Polym. 2019, 207, 91-99. [CrossRef]

39. Ho Jin, Y.; Lee, T.; Rae, J.; Choi, Y.; Park, C. Improved production of bacterial cellulose from waste glycerol through investigation of inhibitory effects of crude glycerol-derived compounds by Gluconacetobacter xylinus. J. Ind. Eng. Chem. 2019, 75, 158-163. [CrossRef]

40. Yassini, F.; Bassil, N.; Flouty, R.; Chokr, A.; El Samarani, A.; Boiteux, G.; El Tahchi, M. Culture medium pH influence on Gluconacetobacter physiology: Cellulose production rate and yield enhancement in presence of multiple carbon sources. Carbohydr. Polym. 2016, 146, 282-291. [CrossRef]

41. Mohammadkazemi, F.; Azin, M.; Ashori, A. Production of bacterial cellulose using different carbon sources and culture media. Carbohydr. Polym. 2015, 117, 518-523. [CrossRef]

42. Leal, I.L.; Carolino, Y.; Penha, S.; Romano, P.; Correia, C.; Melo, S.; Guimarães, D.H.; Dantas, J.; Barbosa, V.; Druzian, J.I.; et al. Development and application starch films: PBAT with additives for evaluating the shelf life of Tommy Atkins mango in the fresh-cut state. J. Appl. Polym. Sci. 2019, 48150, 1-19. [CrossRef]

43. Almeida, D.M.; Woiciechowski, A.L.; Wosiacki, G.; Prestes, R.A.; Pinheiro, L.A. Propriedades físicas, químicas e de barreira em filme formados por blenda de celulose bacteriana e fécula de batata. Polímeros 2013, 23, 538-546. [CrossRef]

44. Schrecker, S.T.; Gostomski, P.A. Determining the water holding capacity of microbial cellulose. Biotechnol. Lett. 2005, 27, 1435-1438. [CrossRef] [PubMed]

45. Machado, B.A.S.; Reis, J.H.O.; da Silva, J.B.; Cruz, L.S.; Nunes, I.L.; Pereira, F.V.; Druzian, J.I. Obtaining nanocellulose from green coconut fibers and incorporation in biodegradable films of starch plasticized with glycerol. Química Nova 2014, 37, 1275-1282. [CrossRef]

46. Machado, B.A.S.; Silva, R.P.D.; Barreto, G.D.A.; Costa, S.S.; Da Silva, D.F.; Brandão, H.N.; Da Rocha, J.L.C.; Dellagostin, O.A.; Henriques, J.A.P.; Umsza-Guez, M.A.; et al. Chemical composition and biological activity of extracts obtained by supercritical extraction and ethanolic extraction of brown, green and red propolis derived from different geographic regions in Brazil. PLoS ONE 2016, 11, e0145954. [CrossRef] [PubMed]

47. Ruka, D.R.; Simon, G.P.; Dean, K.M. Altering the growth conditions of Gluconacetobacter xylinus to maximize the yield of bacterial cellulose. Carbohydr. Polym. 2012, 89, 613-622. [CrossRef] [PubMed] 
48. Demoling, F.; Figueroa, D.; Ba, E. Comparison of factors limiting bacterial growth in different soils. Soil Biol. Biochem. 2007, 39, 2485-2495. [CrossRef]

49. Wang, J.; Tavakoli, J.; Tang, Y. Bacterial cellulose production, properties and applications with different culture methods-A review. Carbohydr. Polym. 2019, 219, 63-76. [CrossRef]

50. Ul-Islam, M.; Wajid, M.; Khan, S.; Shah, N.; Kon, J. Strategies for cost-effective and enhanced production of bacterial cellulose. Int. J. Biol. Macromol. 2017, 102, 1166-1173. [CrossRef]

51. Biyik, H.; Coban, E.P. Evaluation of different carbon, nitrogen sources and industrial wastes for bacterial cellulose production. Eur. J. Biotechnol. Biosci. 2017, 5, 74-80.

52. Kawano, S.; Tajima, K.; Uemori, Y.; Yamashita, H.; Erata, T.; Munekata, M.; Takai, M. Cloning of cellulose synthesis related genes from Acetobacter xylinum ATCC23769 and ATCC53582: Comparison of cellulose synthetic ability between strains. DNA Res. 2002, 9, 149-156. [CrossRef]

53. Valepyn, E.; Berezina, N.; Paquot, M. Optimization of production and preliminary characterization of new exopolysaccharides from Gluconacetobacter hansenii LMG1524. Sci. Res. 2014, 2, 488-496.

54. Ross, P.; Mayer, R.; Benziman, M. Cellulose biosynthesis and function in bacteria. Microbiol. Rev. 1991, 55, 35-58. [CrossRef] [PubMed]

55. Rani, M.U.; Appaiah, A. Optimization of culture conditions for bacterial cellulose production from Gluconacetobacter hansenii UAC09. Ann. Microbiol. 2011, 61, 781-787. [CrossRef]

56. Molina-Ramírez, C.; Castro, M.; Osorio, M.; Torres-Taborda, M.; Gómez, B.; Zuluaga, R.; Gómez, C.; Gañán, P.; Rojas, O.J.; Castro, C. Effect of different carbon sources on bacterial nanocellulose production and structure using the low $\mathrm{pH}$ resistant strain Komagataeibacter medellinensis. Materials 2017, 10, 639. [CrossRef] [PubMed]

57. Lazarini, S.C.; Yamada, C.; Barud, H.S.; Trovatti, E.; Corbi, P.P.; Lustri, W.R. Influence of chemical and physical conditions in selection of Gluconacetobacter hansenii ATCC 23769 strains with high capacity to produce bacterial cellulose for application as sustained antimicrobial drug-release supports. J. Appl. Microbiol. 2018, 125, 777-791. [CrossRef] [PubMed]

58. de Oliveira, S.A.; da Silva, B.C.; Riegel-vidotti, I.C.; Urbano, A.; de Sousa Faria-Tischer, P.C.; Tischer, C.A. Production and characterization of bacterial cellulose membranes with hyaluronic acid from chicken comb. Int. J. Biol. Macromol. 2017, 97, 642-653. [CrossRef]

59. Fang, L.; Catchmark, J.M. Characterization of cellulose and other exopolysaccharides produced from Gluconacetobacter strains. Carbohydr. Polym. 2015, 115, 663-669. [CrossRef]

60. Erbas Kiziltas, E.; Kiziltas, A.; Blumentritt, M.; Gardner, D.J. Biosynthesis of bacterial cellulose in the presence of different nanoparticles to create novel hybrid materials. Carbohydr. Polym. 2015, 129, 148-155. [CrossRef]

61. Stumpf, T.R.; Pértile, R.A.N.; Rambo, C.R.; Porto, L.M. Enriched glucose and dextrin mannitol-based media modulates fibroblast behavior on bacterial cellulose membranes. Mater. Sci. Eng. C 2013, 33, 4739-4745. [CrossRef]

62. Barud, H.D.S.; De Araújo Júnior, A.M.; Saska, S.; Mestieri, L.B.; Campos, J.A.D.B.; De Freitas, R.M.; Ferreira, N.U.; Nascimento, A.P.; Miguel, F.G.; Vaz, M.M.D.O.L.L.; et al. Antimicrobial Brazilian propolis (EPP-AF) containing biocellulose membranes as promising biomaterial for skin wound healing. Evid. Based Complement. Alternat. Med. 2013, 2013, 703024. [CrossRef]

63. Recouvreux, D.O.S.; Rambo, C.R.; Berti, F.V.; Carminatti, C.A.; Antônio, R.V.; Porto, L.M. Novel three-dimensional cocoon-like hydrogels for soft tissue regeneration. Mater. Sci. Eng. C 2011, 31, 151-157. [CrossRef]

64. Mohite, B.V.; Patil, S.V. Physical, structural, mechanical and thermal characterization of bacterial cellulose by G. hansenii NCIM 2529. Carbohydr. Polym. 2014, 106, 132-141. [CrossRef] [PubMed]

65. Costa, A.F.S.; Almeida, F.C.G.; Vinhas, G.M.; Sarubbo, L.A. Production of bacterial cellulose by Gluconacetobacter hansenii using corn steep liquor as nutrient sources. Front. Microbiol. 2017, 8, 2027. [CrossRef] [PubMed]

66. Feng, X.; Ullah, N.; Wang, X.; Sun, X.; Li, C.; Bai, Y.; Chen, L.; Li, Z. Characterization of bacterial cellulose by Gluconacetobacter hansenii CGMCC 3917. J. Food Sci. 2015, 80, E2217-E2227. [CrossRef] [PubMed]

67. Hutchens, S.A.; León, R.V.; O’Neill, H.M.; Evans, B.R. Statistical analysis of optimal culture conditions for Gluconacetobacter hansenii cellulose production. Lett. Appl. Microbiol. 2007, 44, 175-180. [CrossRef] [PubMed]

68. Mohite, B.V.; Salunke, B.K.; Patil, S.V. Enhanced production of bacterial cellulose by using Gluconacetobacter hansenii NCIM 2529 strain under shaking conditions. Appl. Biochem. Biotechnol. 2013, 169, 1497-1511. [CrossRef] 
69. Ishihara, M.; Matsunaga, M.; Hayashi, N.; Tišler, V. Utilization of D-xylose as carbon source for production of bacterial cellulose. Enzym. Microb. Technol. 2002, 31, 986-991. [CrossRef]

70. de Andrade, M.R.; Nery, T.B.R.; de Santana E Santana, T.I.; Leal, I.L.; Rodrigues, L.A.P.; de Oliveira Reis, J.H.; Druzian, J.I.; Machado, B.A.S. Effect of cellulose nanocrystals from different lignocellulosic residues to chitosan/glycerol films. Polymers 2019, 11, 658. [CrossRef]

71. Cheviron, P.; Gouanvé, F.; Espuche, E. Preparation, characterization and barrier properties of silver/montmorillonite/starch nanocomposite films. J. Membr. Sci. 2016, 497, 162-171. [CrossRef]

72. Masclaux, C.; Gouanvé, F.; Espuche, E. Experimental and modelling studies of transport in starch nanocomposite films as affected by relative humidity. J. Membr. Sci. 2010, 363, 221-231. [CrossRef]

73. Azevedo, V.M.; Dias, M.V.; de Siqueira Elias, H.H.; Fukushima, K.L.; Silva, E.K.; de Deus Souza Carneiro, J.; de Fátima Ferreira Soares, N.; Borges, S.V. Effect of whey protein isolate films incorporated with montmorillonite and citric acid on the preservation of fresh-cut apples. Food Res. Int. 2018, 107, 306-313. [CrossRef]

74. Naseri-Nosar, M.; Ziora, Z.M. Wound dressings from naturally-occurring polymers: A review on homopolysaccharide-based composites. Carbohydr. Polym. 2018, 189, 379-398. [CrossRef] [PubMed]

75. Cyras, V.P.; Manfredi, L.B.; Ton-That, M.T.; Vázquez, A. Physical and mechanical properties of thermoplastic starch/montmorillonite nanocomposite films. Carbohydr. Polym. 2008, 73, 55-63. [CrossRef]

76. Мa, X.; Yu, J.; Kennedy, F.J. Studies on the properties of natural fibers-reinforced thermoplastic starch composites. Carbohydr. Polym. 2005, 62, 19-24. [CrossRef]

77. Tunç, S.; Duman, O. Preparation and characterization of biodegradable methyl cellulose/montmorillonite nanocomposite films. Appl. Clay Sci. 2010, 48, 414-424. [CrossRef]

78. Taghizadeh, M.T.; Sabouri, N. Study of enzymatic degradation and water absorption of nanocomposites polyvinyl alcohol/starch/carboxymethyl cellulose blends containing sodium montmorillonite clay nanoparticle by cellulase and $\alpha$-amylase. J. Taiwan Inst. Chem. Eng. 2013, 44, 995-1001. [CrossRef]

79. Majeed, K.; Ahmed, A.; Abu Bakar, M.S.; Mahlia, T.M.I.; Saba, N.; Hassan, A.; Jawaid, M.; Hussain, M.; Iqbal, J.; Ali, Z. Mechanical and thermal properties of montmorillonite-reinforced polypropylene/rice husk hybrid nanocomposites. Polymers 2019, 11, 1557. [CrossRef]

80. Chee, S.S.; Jawaid, M. The effect of Bi-functionalized MMT on morphology, thermal stability, dynamic mechanical, and tensile properties of epoxy/organoclay nanocomposites. Polymers 2019, 11, 2012. [CrossRef]

81. Ul-Islam, M.; Khan, T.; Park, J.K. Water holding and release properties of bacterial cellulose obtained by in situ and ex situ modification. Carbohydr. Polym. 2012, 88, 596-603. [CrossRef]

82. Li, S.; Jia, N.; Zhu, J.; Ma, M.; Sun, R. Synthesis of cellulose-Calcium silicate nanocomposites in ethanol/water mixed solvents and their characterization. Carbohydr. Polym. 2010, 80, 270-275. [CrossRef]

83. de Oliveira Barud, H.G.; da Silva, R.R.; da Silva Barud, H.; Tercjak, A.; Gutierrez, J.; Lustri, W.R.; de Oliveira, O.B.; Ribeiro, S.J.L. A multipurpose natural and renewable polymer in medical applications: Bacterial cellulose. Carbohydr. Polym. 2016, 153, 406-420. [CrossRef] 